\title{
INTEGRATING ISLAMIC MODERATION VALUES IN TEACHING SPEAKING THROUGH GROUP ACTIVITY
}

\author{
Achmad Baidawi ${ }^{1}$ \\ English Teaching and Learning Program, Tarbiyah Faculty, Institut Agama Islam Negeri Madura \\ Pamekasan 69371, Indonesia \\ (achmadbaidawi82@gmail.com) \\ Wahab Syakhirul Alim ${ }^{2}$ \\ English Teaching and Learning Program, Tarbiyah Faculty, Institut Agama Islam Negeri Madura \\ Pamekasan 69371, Indonesia \\ (wahab85alhabsy@gmail.com) \\ Rabi'ah $^{3}$ \\ English Teaching and Learning Program, Tarbiyah Faculty, Institut Agama Islam Negeri Madura \\ Pamekasan 69371, Indonesia \\ (robi'ah_43@yahoo.com)
}

\begin{abstract}
Instilling Islamic moderation values is done to respond to the coming of some people bringing radicalism which is considered to disturb the peace and harmony of the social life of Indonesian people. Islamic moderation is a response to radicalism that must be implanted and infected to young generations. This research was intended to know how Islamic moderation values were implanted and what Islamic moderation values were implemented in teaching speaking through group work activity. This research used descriptive qualitative field research. The data collection instruments were observation and interview. The steps of data analysis were data condensation, data display, and conclusion drawing. This research revealed that the lecturer employed group work activity. In group work activities, the students were divided into seven groups. The member of the group consisted of five or six students. Each student in the group had their roles such as a master of ceremony, moderator, and presenter. In playing their role, they respected one and another. They discussed the topic within the group. No one dominated. After doing a discussion within the group, then each group had their turns to present their topic. If one group were presenting, the rest became the audience and vice versa. Therefore, Islamic moderation values such as Syura (discussion), Tasamuh (tolerant), Tathawur wa Ibtikar (dynamic, creative, and innovative), and Musawah (egalitarian) were implanted and implemented through group work activity in teaching speaking.
\end{abstract}

Keywords: Group Activity; Moderation Value; Speaking

First Received:

(July 28, 2020)
Final Proof Received:

(September 28, 2020)

\section{INTRODUCTION}

Recently in our country radicalism develops more and more rapidly. It can finally threaten nation integration and influence social relationships one and another because radicalism is not the character of Indonesian people. As we have known that Indonesian people consist of various regions, tribes, cultures, languages, and religions. Each of them has its characteristics and principles but they must ignore them because Indonesia was 
naturally born with multi-cultures and pluralism which must keep standing. Indonesia as NKRI is already final and Pancasila as our ideology is fixed.

On the other hand, radicals tend to justify their thought, group, doctrine, and are exclusive. They are not open to other groups. This condition must be resisted with balanced resistance such as implanting Islamicmoderation values to our next generation. Foye in Madkur and Azkia stated that putting the religious value after teaching material successfully taught is no problem (Madkur \& Muharom Albantani, 2018). This statement is also strengthened by Liyanage, Bartlett, and Grimbeek (2010), they stated one of the factors necessary to be involved in learning design is their ethno-religious background. To spread out the Islamic moderation values can be done through some sectors. One of the strategic sectors is in the education one because it is the place to transfer knowledge to the next generation.

Ali (2018: 19) stated that Education plays a pivotal role in building a mode of characters of learners and society. While Kamal strengthened the statement above by stating that education constitutes a strategic pillar to disseminate the values of tolerance, moderation, respect, and empathy, and to develop an attitude of non-violence for learners (Kamal, 2017). From the statements above we have known well that education is as the instrument to transform the knowledge.

Instilling Islamic moderation values must be done not only through religion subjects but also general subjects like Math, Biology, English, and so forth because students as the next generation being in charge of the survival of this nation should be early supplied with Islamic moderation values. Irveanty (2013) stated that with the existence of Islamic character values that have been integrated into every subject in school, especially in English lessons then it is expected that students can apply the values of Islamic character in daily life. In integrating the Islamic moderation value in the teaching and learning process is not hard work. The teacher can choose the teaching methods which cover the classroom activity involving collaborative activity.

There have been many researchers who attempt to study. Here is the study which is in line with the researchers' research from Rahmat Kamal (2017), Internalization of Moderate Islamic Values in Education, IAIN Pekalongan. The objective of the research focused on the internalization of moderate Islamic values in education such as emphasizing the values of moderation between the left-wing extremist group (liberal group) and the right-wing extremist group (fundamental group) and including the values of tolerance, respecting diversity, inclusiveness, logic, and flexibility. The difference between his research and this research is that his research talks about Islamic moderate values in education in a general perspective. While this research tries to find how Islamic moderation values are implemented in teaching Speaking trough group work activity to the first semester of student English Teaching and Learning Program IAIN Madura. This research is expected to give a useful and valuable contribution to 
other lecturers and readers in doing the next research on integrating the Islamic moderation value through teaching and learning activity.

\section{LITERATURE REVIEW}

\section{Islamic Moderation}

Islam constitutes one of the religions that always provides its adherents with the understanding of life intolerance, salvation, and love among others. It is in line with the name of Islam itself. The word "Islam" is derived from the Arabic language "aslamayuslimu-islaman".The term "moderate" possesses the meaning "the attitude of moderation". This form of Islam denotes attitudes to avoid or reduce the extremity of Islam. Moreover, if this term refers to the existence of Islam as the religion of salvation, moderate Islam emphasizes the moderation between over-reacted attitudes and irresponsive attitudes towards religions as well as religious life. (Huda, 2010) and Abou Fadl in Wahyudi (2011), additionally, asserts that the term "moderate" discovers its main source from the precedence of the Qur'an that always encourages Muslims to be moderate persons and the precedence of Hadith that describes Prophet Muhammad (PBUH) as a moderate figure when he encountered two extreme choices and decided to select moderate ways (Wahyudi, 2011).

The precedence of the Qur'an is the term "wasath" mentioned in al-Baqarah Verse 143. This verse explains that Muslims areummatan wasathan. It is moderate Muslims who do not tend to either the left-wing group (liberal group) or the right-wing group (fundamental group). Allah (Swt) said:

"And thus we have made you all a moderate community so that you will be witnesses over the people and the Messenger will be a witness over you..." (al-Baqarah: 143).

Meanwhile, the precedence of Hadith that is meant by Abou Fadl denotes the probability of Rasulullah's say (PBUH) explaining that the best thing is moderation "khairu al-umuri ausathuha". It indicates that moderation is chosen by the prophet Muhammad (PBUH). In other words, Islamic Moderation is one of the main characteristics of a Muslim individual's conduct and the Muslim community's living style, in many aspects of their daily life.

Its reflection can be observed from their acceptance of the factuality of worldly life together with their struggle for the Hereafter in a combinatorial approach. It strikes a balance between the requirements of spiritual activities and the requirements of material and physical tasks and responsibilities. This is the nature of the Islamic Moderation model that was demonstrated and practiced by the Prophet (PBUH) in educating and shaping his companions where the elements of materialism and spiritualism were always kept in good balance and function. 


\section{Moderate Islamic Values}

According to the Great Dictionary of the Indonesian Language (KBBI), the word "value" is epistemologically defined as (a) price, (b) price of money, (c) level of intelligence, (d) quantity, (e) useful things for humanity, and (f) things that humanizing humans by their dignity (Badan Bahasa Depdiknas, 2014). Meanwhile, Zakiyah Darajat views "value" as the thickening of belief or feeling, which is deemed/ considered to be the identity that contributes special characteristics of ways of thinking, feeling, relationship, or behavior (Darajat, 1989).

Based on those definitions, it can be stated that "value" is an abstract thing, which is useful in life and employed as the thickening of belief and guideline for humans' behavior in their daily lives. Moreover, value has a strong correlation with feeling. It is because if something is valuable, it tends to give a positive feeling. Conversely, if something does not have any value, it tends to cause a negative feeling. It proposes that the process of education is required to build values to be the awareness and thickening of belief.

Likewise, the objects of value include actions, things, facts, events, and norms. All the objects orientate themselves towards the significance of value by concerning humans' consideration (the value of humanity) and the consideration that is initiated knowledge and the awareness of divine values (Rohmat Mulyana, 2004).

Toto Suharto's concept of Islam emphasizes the principles of rahmatan lil-'alamin, which is pointed out by Abudin Nata, there are ten fundamental values of moderate Islamic education, which is further Islamic education of rahmatan lil-'alamin identified as the indicators, namely: (1) the peaceful education that respects human rights and the social transformation among nations, races, and groups ofreligion; (2) the education that develops entrepreneurship skills and a good relationshipin the world of industry; (3) the education that deems the vision of prophetic Islam,including humanization, liberation, and transcendence for social transformation; (4) the education that contains the teachings of tolerance in religious life and pluralism; (5) theeducation that promotes moderate Islam of Indonesia; (6) the education that balances intellectual insights (head), spiritual knowledge as well as good characters (heart), andvocational skills (hand); (7) the education that graduates intellectual ulema (Islamic scholars) as well as ulema-based intelligence; (8) the education that proposes solutions tocurrent problems in education, including the dualism and methods of teaching andlearning; (9) the education that emphasizes the quality of education comprehensively,and (10) the education that is able to encourage the mastery of foreign languages (Suharto, 2017).

Islamic values in Islamic moderation include (Suara Nahdlatul Ulama / NU Online, 2019). The first is Tawassuth (take the middle ground), ie understanding and practice are not ifrath (exaggeration in religion) and tafrith (reducing religious teachings). The second is tawazun (balanced) that the understanding and practice of religion in a balanced way that includes all aspects of life both temporal and hereafter, emphatic in stating principles 
that can distinguish between inhiraf (deviation) and the deviation (difference). The third is I'tidal (straight and firm), i.e. putting things in place and implement the right and fulfill the obligation proportionally. The fourth is Tasamuh (tolerance) that recognizes and respects diversity, both in the religious aspects and various other aspects of life. Tolerance is the quality of allowing other people to say and do as they like, even if you do not agree or approve of it (Collin English Dictionary, 2020). Based on KBBI tolerance means nature or be tolerated (appreciate, let, to allow) the establishment of (ideas, opinions, beliefs, habits, behavior, and so on) are contrary to the establishment of its own. In short, Tolerance or Tasamuh is the nature to receive the difference.

The fifth is Musawah (egalitarian) which does not discriminate on the other due to differences in belief or religion, tradition and origin of a person. The sixth is Shura (consultation) that each issue is resolved by way of deliberation to reach a consensus with the principle of putting the benefit of all. Syura or discussion is the activity in which people talk about something and tell each other their ideas or opinions (Cambridge English Dictionary, 2020). So, shura as the process of exposing the various opinions were diverse and accompanied argumentative side in a case or problem, tested by experts intelligent and understanding, in order to trigger the right solution and the best to be carried out so that the goals are expected to be realized. The seventh is Islah (reform) that prioritizes the principle of reformative to reach a state better accommodate changes and the progress of time the basis of the common good (mashlahah 'amah) by sticking to the principle of almuhafazhah' ala al-qadimi al-salih wa al-akhdzu bi al-jadidi al-ashlah (taking care of the tradition to respond to modernization). The eighth is aulawiyah (triaging of priority): the ability to identify individual things that are more important to be preferred to be implemented compared to the lesser importance. The ninth is Tathawwur wa Ibtikar (dynamic and innovative) are always open to make changes in accordance with the times, and create new things for the welfare and progress of humanity. The tenth is Tahadhdhur (civilized) that uphold good attitude, character, identity and integrity as khairuummah in the life of humanity and civilization.

To cultivate the Islamic moderation values to the next generation can be done in some ways. One of the ways is through group activity in teaching speaking.

\section{Group Work Cctivity}

Group activity is a classroom activity that involves two or more students in a group. Through this group activity, class activity is designed to make the learning activity more interesting and active. Besides, this activity trains the students to work together with other students so that they must respect, understand, and help one and another. They also take their turns based on their role in group activity. Group activity is the class activity that is done by a group of students at least two or more students in the learning process so that group activity can encourage students to build a social relationship one and another. 
In line with this, Gillies \& Ashman in (Febrina: 2013) state that group work, in a language class, is a cooperative activity, it is designed and implemented to develop social strategies and acceptable social attitudes in students and to improve social relations within and between groups. In the cooperative activity, the students share aims and responsibilities to complete a task assigned by the teacher in groups or pairs. Nila Febrina, Mukhaiyar, M. Zaim (2013) Using group activity in the teaching and learning process can stimulate students to be more active and work together to share knowledge and experience. According to Douglas in Nila et all, group work can develop the students to interact with other students (2013). Besides, group work activity can complete one and another because some students have some weaknesses and some have strengths. In the teaching and learning process, group activity is very suggested to do to avoid individual activity. John says that group work is an important part of many different teaching approaches (John, 2017).

\section{Kinds of Group Work Activity}

Harmers (2015) states that there are four types of group activities, they are:

a. Information gaps, the classroom technique is where one student misses information and another student has it.

b. Surveys, one way to encourage conversation and opinion exchange is to get students to conduct questionnaires and surveys.

c. Discussion, here the students are divided into some groups, and each group is given a topic to discuss within and present in front of other groups.

d. Role-play, students are suggested to choose figures and their idols and ask them to act like them.

Whereas Brown (2007) states that there are ten kinds of group work.

a. Games, the game is a fun classroom activity that cannot be done individually. Many kinds of games can be used to activate all students in classroom activities.

b. Role-plays and simulation, students are asked to act as if they are a presenter of a TV program, a boss, etc.

c. Drama, this activity needs students to prepare the story script before playing the drama.

d. The project, a teacher assigns each group to do their project, for example, one group is asked to do a mini research on school healthy environment and later report it in front of the class.

e. Interview, this activity is also useful for group work. Students can try practicing speaking by asking information to the interviewee and answer the question to the interviewer.

f. Brainstorming, this technique is usually used in group work to gather any idea from each member of a group without criticizing the idea. 
g. The Information gap, this activity is used to make students more active and communicative because this group work activity is to complete the missing information which is only found by other students.

h. Jigsaw activities, this group work activity divides the students into some groups of 3-5 members. The teacher gives each group some topics to discuss.

i. Problem-solving and decision making, this activity focuses on making decisions and finding the solution to the problem given by the teacher rather than focuses on the grammatical or phonological forms.

j. Opinion exchange, this activity can be done through classroom debate and discussion.

\section{The Advantage of Group Work Activity}

According to Brown, there are four advantages of group work activity (2007). The first is group work generates interactive language. Through the group, the students have more time to interact with other students and the teacher is not dominant in the teaching and learning process. The second is group work offers an embracing effective climate. Each student has strengths and weaknesses so that group work can creat nice circumstances especially for students who are shy and have low self-confidence. The third is group work promotes learner responsibility and autonomy. In group work, students fell that they have a responsibility to help one and another and they can determine what they should do in a group. The fourth is group work is a step toward individualizing instruction. Every student comes with their differences either in intelligence, self-confidence, personality, or others. To accommodate students' needs, group work should be applied.

\section{Definition of speaking}

Speaking is an interactive process of constructing meaning that involves producing and receiving and processing information (Bailey \& Savage, 1994). Furthermore, speaking is defined as the development of the relationship between speaker and listener. It means that speaking activity can not be done alone. A speaker needs an interlocutor to converse to convey what he has in his mind. Besides, speaking is also used to maintain a social relationship. Speaking is the activity which is always done by people in their daily life almost every second to convey what they feel, need, and think so that the ability to master speaking skills is very crucial especially for English learners as a second or even a foreign language. Mastering speaking skills need extraordinary effort because in speaking the speaker does not only need a series of words, phrases, clauses, and sentences but also ideas, bravery, self-confidence, and knowing with/ to whom we are speaking. Speaking skill is considered as the main standard to measure that someone maters and knows one language. Speaking ability is used to communicate with other people, however; when we are speaking with other people we must show that we are not the ones who dominate the activity, know everything, and feel we are the best of all. 
To help students to be able to have excellent proficiency in speaking, the teacher should apply effective methods as an effort to gain the learning objectives. The selected method, of course, is a solution to overcome learning constraints. Because speaking is a part of communication which involves at least two speakers, we must be able to respect other people and give chance to them. To act wisely in communication, we need to practice Islamic moderation values. The values must be implanted through teaching-learning activity in this case group activity.

Based on the discussion above, the researcher researched how Islamic moderation values were implanted and what Islamic moderation values were implemented in teaching speaking through group activity at the first semester students of the English Study Program of State Islamic Institut of Madura.

\section{METHOD}

This research used descriptive qualitative, field research which tried to get a description of how Islamic moderation values are implanted and what Islamic moderation values are implemented in teaching speaking through group activity since the data obtained in the field in the form of social phenomena were analyzed and presented descriptively. In this research, the researcher describes the phenomena based on the reality that happened and found in the field. The subjects in this study were the first semester students of and speaking lecturers at English Teaching and Learning Program IAIN Madura. In data collection, the researcher used a structural technique of interview with the lecturer. In this study, the observation technique was employed in the classroom. Then, the data which had been obtained were then thoroughly analyzed with a descriptive analysis method, namely data condensation, data display, and conclusion drawing.

\section{RESULTS AND DISCUSSION}

\section{Results}

\section{The way to implant Islamic moderation values}

Because of the importance of applying Islamic moderation values, many ways must be done to instill Islamic moderation values to the young generation in many sectors. In the education sector, they can be integrated into the teaching and learning process through the appropriate selection of teaching methods. Based on the result of data collection through interviews, the lecturer implanted the Islamic moderation values through group work activity. He stated that in implanting the Islamic moderation values, she applied group work activity in this case classroom discussion and presentation. To practice group work, first, he divided the students into seven groups of five or six members. The group members were selected by considering students' conditions such as intelligence, personality, and character. Second, each group was asked to choose the 
discussion of the topic prepared by the teacher by lottery. Third, each group was given a chance in seven minutes to discuss the topic within the group member before presenting in front of other groups. Then, he explained the rules of presentation. After that, each group is pleased to present in turns. While one group was presenting, the rest of the group were listening to the presentation as the audience.

Also, dealing with integrating Islamic moderation values, he further said that group activity could be a media to instill Islamic moderation values because in group activity the students were trained to work together with other students within the group member. In this process, each student with different backgrounds of personality, character, family, intelligence, and egoism must be united to share knowledge and idea about the topic in their group. No one in the group could force his/ her idea or even dominated the discussion. Besides, after discussing the topic within the group member, all groups in turns presented their topic in front of the class while the rest of the group were listening to the presentation. In the presentation session, the rest of the group as audiences were also demanded to respect the presentation group by not talking and then criticizing the idea by asking some questions related to the topic discussion. Therefore, automatically the Islamic moderation values such Syura (Discussion), Tasamuh (Tolerant), Tathawur wa Ibtikar (Dynamic, creative, and innovative), and Musawah (egalitarian) were applied through group activity.

The result of the interview with the lecturer above was strengthened by the result of observation which was conducted by the researcher. The researcher himself as a nonparticipatory observer. It was found that at the time the lecturer applied classroom discussion and presentation as group work activity in teaching speaking. The researcher paid attention to the students activity in speaking class. After they were divided into groups and got instruction from the lecturer, they directly mingle with the group member to share ideas to discuss their group topic. In the discussion process, no one dominated the session and forced their idea to be agreed upon. Each of them in turn took their chance to talk if they had an idea. Further, I noticed that they tried to accommodate any idea expressed by the group member. Besides, they also discussed who was going to be Master of Ceremony, moderators, and presenters. Everything they wanted to do was talked together before. From the result of the researcher's observation, the Islamic moderation values such as Syura (Discussion), Tasamuh (Tolerant), Tathawur wa Ibtikar (Dynamic, creative, and innovative), and Musawah (egalitarian).

\section{The Islamic moderation values implemented}

In group work, all students were involved in the activity whether within their group or in classroom activities such as classroom discussion and presentation. From the result of observation, the Islamic moderation values which were applied were Syura (discussion), Syura or discussion is the activity in which people talk about something and 
tell each other their ideas or opinions, Tasamuh (tolerance) recognizing and respecting diversity, both in the religious aspects and various other aspects of life. Tolerance is the quality of allowing other people to say and do as they like, even if you do not agree or approve of it, Tathawwur wa Ibtikar (dynamic and innovative) are always open to making changes following the times, and create new things for the welfare and progress of humanity, and Musawah (egalitarian) which does not discriminate on the other due to differences in belief or religion, tradition and origin of a person. These values were depicted from the process of opinion exchange process starting from the discussion within the group members and group presentation session. All students seemed to work together to share their ideas related to the group topic and they paid attention to the presentation and responded it by asking questions and giving comments.

\section{Discussion}

A peaceful life is the dream of all people in the world including in Indonesia. Indonesia whose people consist of diverse tribes, cultures, religions, regions, and languages is easy to conflict if it is not well-managed. So far after its independence, Indonesia is a peaceful country but nowadays the peace is disturbed because there some groups of people who bring radicalism in understanding and practicing religion teaching. The danger of radicalism which develops rapidly in our country should be seriously and accurately anticipated to be able to overcome it well. The best thing to do is instilling Islamic moderation values into our generation. In response to the danger of radicalism, strategic ways are needed to do. One of them is through the education sector in this case integrating Islamic moderation values through the teaching and learning process. Educational institutions especially high education institutions must play their strategic role to demolish radicalism. The Islamic moderation values must be inserted in the teaching and learning process so that the students have moderate understanding and behavior.

Based on the result of observations and interviews, the lecturer employed group work activity in teaching speaking. Group work activity in teaching speaking is the classroom activity that involves all students to participate in the teaching and learning process. Therefore, they must work together to discuss their topic. This activity encourages students to be sensitive and respect one and another. They must also be ready to accept differences occurring either idea, attitude, or way of conveying opinion. Besides, the result of observations and interviews showed that there were several values of Islamicmoderation that can be taken from the integration process of Islamic moderation values in teaching speaking through group work activity. The details will be presented as follows :

a. Syura (Discussion)is the process of talking about something together and telling one and another. The students discussed things dealing with the topic. They tried to gather their idea to be united to get the conclusion to be agreed together. 
b. Tasamuh (Tolerant) is when we allow people to do what they want to although we do not agree and dislike it. In doing group work activity, they received any difference happening in the classroom activity but they respected one and another.

c. Tathawur wa Ibtikar (Dynamic, creative, and innovative) is when we are always energetic, have some ideas to create something new to solve some problems in different ways. Group work activity stimulated the students to bear the novel ideas and find fresh solutions to the topic problems being discussed.

d. Musawah (egalitarian) is the attitude when we think that everyone has the same freedom and chance to do something. Group work activity automatically involved all students in the class to participate because they have the same chance and right.

These values which appeared in teaching speaking through workgroup activity can further be practiced by the students when they interact and communicate with people in social life wherever they are. They are supposed to behave moderately so that they easily adapt to a novel environment.

This current research highlights four Islamic moderation values namely Syura (Discussion) in finding the solution of the problem discussed, Tasamuh (Tolerant) in responding to the difference, Tathawur wa Ibtikar (Dynamic, creative, and innovative) in stating an opinion and finishing the task, and Musawah (egalitarian) in interacting with others. Whereas the previous research was done by (Huda, 2010) shown five Islamic moderation values such as the value of objectivity, tolerance, inclusiveness, logic and flexibility, and innovation. Therefore, this research and the previous one has a similarity in implanting Islamic moderation value such as tolerance and innovation. On the other hand, both pieces of research have differences especially in terms of research focuses.

\section{CONCLUSION}

Islamic moderation values as a response to radicalism nowadays must keep being infected and instilled. Many ways can be done to instill them. One of them through the education sector in this case integrated into the teaching and learning process. In the teaching and learning process to instill Islamic moderation values, the lecturer employed group work activity by dividing the students into seven groups consisting of five or six students in each group to work together to share their idea dealing with topics. From that group work activity, the Islamicmoderation value such as Syura (discussion), Tasamuh (tolerant), Tathawur wa Ibtikar (dynamic, creative, and innovative), and Musawah (egalitarian) automatically appeared and applied.

\section{REFERENCES}

Ali, F. (2018). Incorporating Values of Moderate Islam for the 21st Century Learners in an English as a Foreign Language Class. Edukasia Islamika, 3(1), 8-31. https://doi.org/10.28918/jei.v3i1.1676. 
Achmad Baidawi, Wahab Syakhirul Alim, \& Rabi'ah, Integrating Islamic Moderation ...

Badan Bahasa Depdiknas. (2014). Kamus Besar Bahasa Indonesia (4 ed.). Jakarta: Gramedia.

Bailey, K. M., \& Savage, L. (1994). New Ways in Teaching Speaking. New Ways in TESOL Series: Innovative Classroom Techniques. Alexandria: TESOL.

Brown, H. D. (2007). Teaching by Principles:An Interactive Approach to Language Pedagogy (2 ed.). London: Longman.

Cambridge English Dictionary. (2020). Discussion. https://dictionary.cambridge.org/dictionary/english/discussion.

Collins English Dictionary. (2020). Tolerance Definition and Meaning. https://www.collinsdictionary.com/dictionary/english/tolerance.

Darajat, Z. (1989). Dasar-Dasar Agama Islam. Jakarta: Bulan Bintang.

Febrina, N., Mukhaiyar, \& Zaim, M. (2013). The Study of Using Group Work Teaching Speaking Activity: A Case Study at Grade X MAN 1 Padang. Journal English Language Teaching (ELT), 1(1), 89-101.

H. Douglas Brown. (2007). Teaching by Principles, An Interactive Approach to Language Pedagogy (3rd Edition). San Francisco: San Francisco State University.

Harmer, J. (2015). The Practice of English Language Teaching. London: Pearson Education.

Huda, A. (2010). Epistemologi Gerakan Liberalis, Fundamentalis, dan Moderat Islam di Era Modern. Journal de Jure, 2(2), 178-194. https://doi.org/10.18860/j-fsh.v2i2.2977.

Irveanty, M. (2013). Integrasi Nilai-Nilai Karakter Islami dalam Pembelajaran Bahasa Inggris di SMAN Banjarbaru [Unpublished Thesis]. IAIN Antasari.

John, D. (2017). Employing Group Work to Foster Speaking Skills: A Study of Success and Failure in the Classroom. MEXTESOL Journal, 41(3), 1-9.

Kamal, R. (2017). Internalization of Moderate Islamic Values in Education. Islamic Studies Journal for Social Transformation, 1(1), 67-80. https://doi.org/10.28918/isjoust.v1i1.1142.

Liyanage, I., Bartlett, B., \& Grimbeek, P. (2010). Religious Background and Language Learning: Practical Suggestions for Deriving Best Practice in ELT. The Asian EFL Journal, 46, 28-47.

Madkur, A., \& Muharom Albantani, A. (2018). Instilling Islamic Values in Foreign Language Teaching: An Indonesian Context. Proceedings of the International Conference on Education in Muslim Society (ICEMS 2017). International Conference on Education in Muslim Society (ICEMS 2017), Banten, Indonesia. https://doi.org/10.2991/icems17.2018.20.

Rohmat Mulyana. (2004). Mengartikulasikan Pendidikan Nilai. Bandung: Alfabeta.

Suara Nahdlatul Ulama / NU Online. (2019). Diambil 21 Oktober 2019, dari https://www.nu.or.id/.

Suharto, T. (2017). Indonesianisasi Islam: Penguatan Islam Moderat dalam Lembaga Pendidikan Islam di Indonesia. Al-Tahrir: Jurnal Pemikiran Islam, 17(1), 155-178178. https://doi.org/10.21154/altahrir.v17i1.803.

Wahyudi, C. (2011). Tipologi Islam Moderat dan Puritan: Pemikiran Khaled M. Abou elFadl. Teosofi Jurnal Tasawuf dan Pemikiran Islam, 1(1), 75-92. https://doi.org/10.15642/teosofi.2011.1.1.75-92. 